\title{
Pre-Diagnosis Gangguan Ginjal Melalui Citra Iris Mata Menggunakan Raspberry PI Dengan Metode Convolutional Neural Network (CNN)
}

\author{
Indra Agustian ${ }^{1}$, Faisal Hadi ${ }^{1}$, M. Khairul Amri Rosa ${ }^{1}$ \\ ${ }^{1}$ Teknik Elektro Unviversitas Bengkulu \\ indraagustian@unib.ac.id
}

\begin{abstract}
ABSTRAK
Penelitian ini melakukan perancangan aplikasi pengenalan gangguan ginjal dini melalui citra digital iris mata menggunakan metode convolutional neural network (CNN) dengan antarmuka Raspberry Pi 3 model B+. Hasil akurasi terbaik yang diperoleh dengan memvariasikan banyak epoch, nilai learning rate, ukuran kernel, komposisi database, dan fungsi pooling layer adalah $94 \%$ pada saat epoch $12,92 \%$ pada nilai $0,0001,95 \%$ pada ukuran $3 \times 3,95 \%$ pada komposisi 100 train dan 50 validation, $90 \%$ menggunakan fungsi max pooling.

Kata kunci: gangguan ginjal, iridology, convolutional neural network, raspberry pi.
\end{abstract}

\section{PENDAHULUAN}

Perubahan pola penyakit tanpa disadari telah memberi pengaruh terhadap terjadinya transisi epidemiologi, dengan semakin meningkatnya kasuskasus penyakit tidak menular. Menurut WHO (World Health Organization), pada tahun 2005 proporsi kesakitan dan kematian di dunia yang disebabkan oleh penyakit tidak menular sebesar $47 \%$ kesakitan dan 54\% kematian, dan diperkirakan pada tahun 2020 proporsi kesakitan ini akan meningkat menjadi 60\% dan proporsi kematian menjadi $73 \%$. Pada tahun 2008 terdapat 57 juta kematian di dunia, dimana Proportional Mortality Rate (PMR) penyakit tidak menular di dunia adalah sebesar 36 juta (63\%). Angka penyakit tidak menular juga terus mengalami peningkatan. Salah satu penyakit yang juga mengalami peningkatan adalah gangguan ginjal [1]

Gangguan ginjal merupakan penurunan fungsi ginjal progresif yang irreversible ketika ginjal tidak mampu mempertahankan keseimbangan metabolik, cairan, dan elektrolit yang menyebabkan terjadinya uremia dan azotemia. The United States Renal Data System (USRDS) mencatat bahwa jumlah pasien yang dirawat karena End Stage Renal Disease (ERDS) terkena gangguan ginjal atau gagal ginjal kronis diperkirakan 3.010.000 pada tahun 2012 dengan tingkat pertumbuhan 7\%. Prevalensi gangguan ginjal salah satunya yaitu Gangguan Ginjal Kronik (GGK) terus mengalami peningkatan misalnya, di Taiwan (2.990/1.000.000 penduduk), jepang (2.590/1.000.000 penduduk), dan Amerika serikat (2.020/1.000.000 penduduk) [2][3].

Tingginya prevalensi GGK juga terjadi di Indonesia, karena angka ini dari tahun ke tahun terus mengalami peningkatan. Jumlah penderita gagal ginjal kronis di Indonesia pada tahun 2011 tercatat 22.304 dengan 68,8\% kasus baru dan pada tahun 2012 meningkat menjadi 28.782 dengan 69,1\% kasus baru. Hal ini menyebabkan banyaknya penderita gangguan ginjal di Indonesia. Pada tahun 2013 jumlah penderita GGK mencapai 504.248 jiwa. Keadaan ini menunjukkan bahwa penderita gangguan ginjal di Indonesia masih sangat tinggi. Penyebabnya tidak hanya dari pola hidup. Namun, kurangnya kesadaran untuk mengetahui gejala-gejala gangguan ginjal, padahal gangguan ginjal dapat diketahui dengan melihat iridologi mata [2][4].

Iridologi adalah diagnosa iris atau selaput pelangi mata manusia yang mampu merefleksikan kondisi kesehatan tubuh dan emosi seseorang. Hal tersebut disebabkan iris mata manusia mengandung 28.000 saraf-saraf halus yang berhubungan dengan sel tubuh. Saraf-saraf halus tersebut terdiri dari saraf simpatis dan parasimpatis yang mampu merefleksikan kondisi tubuh dan emosi seseorang melalui iris mata. Kondisi kesehatan tubuh yang dapat diketahui dengan memanfaatkan teknologi iridologi melalui citra iris mata diantaranya adalah keadaan pada pankreas, hati, otak, paru-paru dan gangguan pada ginjal [5].

Sementara itu, kemajuan teknologi yang terus berkembang dalam dunia kesehatan terkhusus di bidang iridologi, membawa dampak positif di bidang biomedis dengan memanfaatkan teknologi kecerdasan buatan (Artificial Intelligent) beberapa macam 
diantaranya adalah Fuzzy Logic, Hidden Markov Model (HMM), Support Vector Mechine (SVM). Fuzzy Logic merupakan kecerdasan buatan yang sederhana, variasi kondisi tiap citranya terbatas, dan ketepatan mempresentasikan citra terbatas. Sementara itu, Hidden Markov Model (HMM) merupakan kecerdasan buatan yang bergantung dengan nilai False Acceptance Rate (FAR) dan False Rejection Rate (FRR), sehingga perlu adanya teknologi kecerdasan buatan yang lebih baik salah satunya kecerdasan buatan yang akan digunakan pada penelitian ini menggunakan Convolution Neural Network (CNN) yang memiliki kelebihan ketepatan mempresentasikan citra berdasarkan jumlah dataset dan parameter arsitektur model [6].

Pada penelitian ini, akan melakukan perancangan software dan hardware mendiagnosis gangguan ginjal dengan pengolahan citra digital iris mata menggunakan Raspberry Pi 3 Model $\mathrm{B}+$ dengan metode CNN.

\section{KERANGKA TEORITIS DAN PENGEMBANGAN HIPOTESIS}

\section{A. Convolutional Neural network (CNN)}

Convolutional Neural network (CNN) merupakan pengembangan dari multilayer layer perceptron (MLP) yang didesain untuk mengolah data dua dimensi dalam bentuk citra. CNN ini termasuk kedalam jenis Deep Neural network karena kedalaman jaringan yang tinggi dan banyak diaplikasikan pada data citra yang rumit. Pada dasarnya klasifikasi citra dapat menggunakan MLP saja, akan tetapi dengan metode MLP kurang sesuai untuk digunakan karena tidak dapat menyimpan informasi spasial dari data cita dan menganggap setiap piksel adalah fitur yang independen sehingga menghasilkan hasil yang kurang baik. Secara teknis CNN adalah sebuah arsitektur yang dapat dilatih dan terdiri dari beberapa tahap. Masukan (input) dan keluaran (output) dari setiap tahap adalah terdiri dari beberapa array yang biasa disebut feature map. Setiap tahap terdiri dari tiga layer yaitu convolutional layer, fungsi aktivasi layer, dan pooling layer dapat dilihat pada gambar 1 yang merupakan arsitektur jaringan $\mathrm{CNN}$.

\section{B. Convolution Layer}

Convolution layer merupakan bagian dari tahap pada arsitektur CNN. Tahap ini melakukan operasi

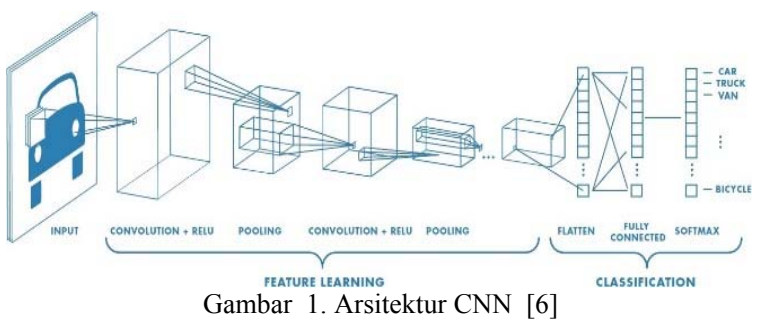

konvolusi pada output dari layer sebelumnya[7]. Layer tersebut adalah proses utama yang mendasari jaringan arsitektur CNN. Operasi ini menerapkan fungsi output sebagai Feature Map dari input citra. Operasi konvolusi dapat dituliskan sebagai Persamaan 1.

$$
\begin{aligned}
& s(t)=(x * t)(t)=\sum_{a=-\infty}^{\infty} x(a) \\
& * w(t-a) \\
& \text { dengan: } \\
& \mathrm{s}(\mathrm{t})=\text { Fungsi hasil operasi konvolusi } \\
& \mathrm{x} \quad=\text { Input } \\
& \mathrm{w}=\text { bobot (kernel) }
\end{aligned}
$$

\section{Fungsi Aktifasi}

Fungsi aktivasi merupakan fungsi yang menggambarkan hubungan antara tingkat aktivitas internal (summation function) yang mungkin berbentuk linear ataupun nonlinear. Fungsi ini bertujuan untuk menentukan apakah neuron diaktifkan atau tidak. Beberapa fungsi aktivasi yang sering digunakan dalam Neural Network

\section{Operasi Pooling}

Pooling merupakan pengurangan ukuran matriks dengan menggunakan operasi pooling. Pooling layer biasanya berada setelah conv. Pada dasarnya pooling layer terdiri dari sebuah filter dengan ukuran dan stride tertentu yang akan secara bergantian bergeser pada seluruh area feature map. Pooling layer terdapat dua macam pooling yang biasa digunakan yaitu average pooling dan maxpooling. Nilai yang diambil pada average pooling adalah nilai rata-rata, sedangkan pada max-pooling adalah nilai maksimal[7].

\section{Fully Connected Layer}

Fully Connected Layer adalah sebuah lapisan dimana semua neuron aktivasi dari lapisan sebelumnya terhubung semua dengan neuron di lapisan selanjutnya sama seperti halnya dengan neural network biasa. Perbedaan antara lapisan fully connected dan lapisan konvolusi biasa adalah neuron di lapisan konvolusi terhubung hanya ke daerah 


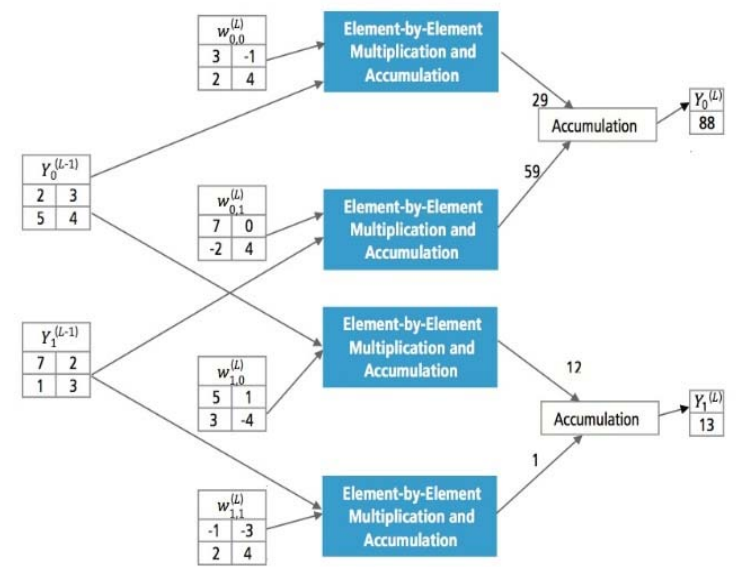

Gambar 2. Processing of a Fully Connected Layer [6]

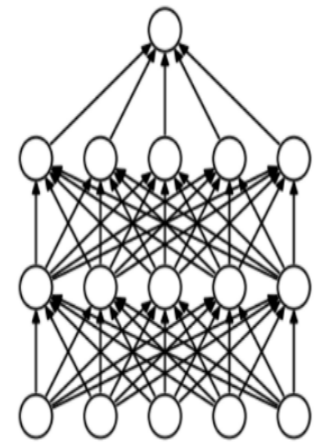

(a)

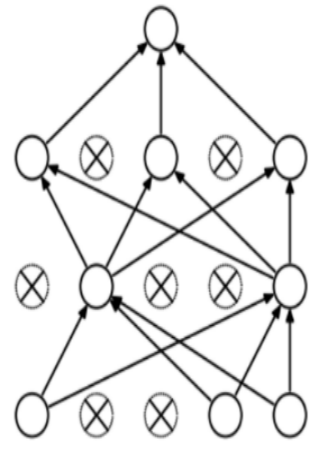

(b)
Gambar 3. Dropout Regulation (a) Standard Neural Network (b) Neural Net with Dropout [6]

tertentu pada input, sementara lapisan fully connected memiliki neuron yang secara keseluruhan terhubung. Namun, kedua lapisan tersebut masih mengoperasikan produk dot, sehingga fungsinya tidak begitu berbeda. Berikut ini adalah proses fully connected yang dapat dilihat pada Gambar 2. [11].

4. Dropout Regulation

Dropout merupakan sebuah teknik regulasi jaringan saraf dengan tujuan memilih beberapa neuron secara acak dan tidak akan dipakai selama proses pelatihan, dengan kata lain neuron-neuron tersebut dibuang secara acak [12]. Hal ini berarti bahwa kontribusi neuron yang dibuang akan diberhentikan sementara jaringan dan bobot baru juga tidak diterapkan pada neuron pada saat melakukan backpropagation. Berikut proses dropout dapat dilihat pada Gambar 7.

Berdasarkan Gambar 3 pada bagian (a) merupakan jaringan saraf biasa yang memiliki dua hidden layer. Sedangkan pada bagian (b) merupakan jaringan saraf dengan menggunakan dropout. Gambar

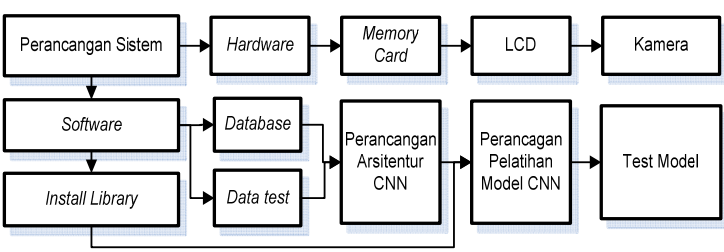

Gambar 4. Diagram Blok Sistem Perancangan

tersebut terlihat terdapat beberapa neuron aktivasi yang tidak dipakai lagi. Penggunaan teknik ini sangat mudah diimplementasikan pada model CNN dan akan berdampak pada performa model dalam melatih serta mengurangi overfitting. Pada jaringan saraf tiruan biasa, dimisalkan $y l$ adalah nilai keluaran dari suatu lapisan $l$ dan $z l$ adalah nilai masukan pada layer $l$ dengan $W l$ dan $b l$ adalah bobot dan bias dari lapisan $l$, dengan unit ke $i$ maka perhitungan proses feedforward menggunakan fungsi aktivasi $f$ dapat dilakukan pada Persamaan 2 dan 3.

$$
\begin{aligned}
& z_{i}^{l+1}=w_{i}^{(l+1)}+b_{i}^{(l+1)} \\
& y_{i}^{l+1}=\left(z_{i}^{(l+1)}\right)
\end{aligned}
$$

Sementara itu, pada jaringan yang mengimplementasikan teknik dropout, variable $r l$ melambangkan vektor sepanjang $j$ yang menyimpan nilai yang diperoleh dari distribusi Bernoulli. Proses feedforward dilakukan pada Persamaan 4, 5, dan 6.

$$
\begin{aligned}
& y^{\sim 1}=\left(y_{j}^{l}+y^{l}\right) \\
& z_{i}^{l}=W_{i}^{(l+1)} y^{l}+b_{i}^{(l+1)} \\
& y_{i}^{l+1}=f\left(z_{i}^{(l+1)}\right)
\end{aligned}
$$

\section{METODE RISET}

Tahap perancangan siste secara garis besar dibagi menjadi dua tahap, yaitu tahap perancangan software dan hardware. Tahap perancangan hardware terbagi menjadi beberapa tahap diantaranya pemasangan memory card, pemasangan LCD, dan pemasangan kamera, sedangkan tahap perancangan software diantaranya pembentukan database, pembentukan data test, perancangan arsitektur convolutional neural network $(\mathrm{CNN})$, perancangan pelatihan model CNN, perancangan test model. Sistem perancangan secara keseluruhan dapat dilihat pada Gambar 4. 


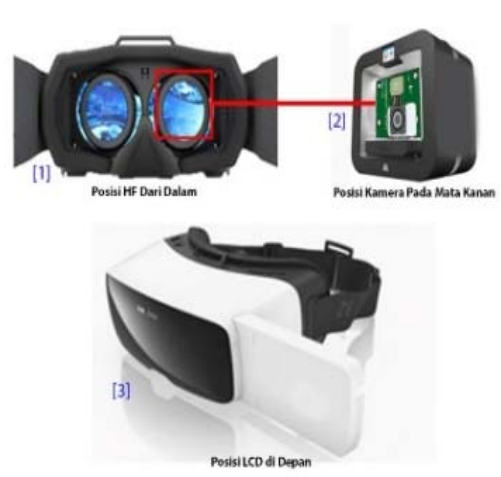

Gambar 5. Desain Perancangan

\section{A. Perancangan Hardware}

Perancangan hardware pada blok diagram memerlukan memory card pada slot memory Raspberry Pi yang berfungsi sebagai tempat penyimpanan data operasi sistem dan data seluruh data pelengkap lainnya. Selanjutnya akan dipasang LCD dengan ukuran 4 inci yang berfungsi sebagai interface sistem. Kemudian perancangan selanjutnya menggunakan kamera logitech C525 sebagai masukan data citra digital. Semua sistem hardware akan dihubungkan dengan Raspberry Pi yang merupakan otak sistem kendali untuk mengolah data citra digital sebagai pengambilan keputusan keluaran pada sistem deteksi gangguan ginjal. Raspberry Pi akan menerima data dari kamera berupa citra digital dan kemudian disimpan sebagai data masukan. Data citra digital akan diproses menggunakan metode $\mathrm{CNN}$ untuk dilatih dan selanjutnya akan terbentuk model dari pelatihan tersebut, sehingga akan memberikan keluran berupa data pemodelan yang telah diproses dan akan di tampilkan ke LCD. Berikut merupakan desain perancangan hardware yang dapat dilihat pada gambar 5.

Berdasarkan gambar 5 dapat dilihat desain dari hardware dengan posisi kamera berada tepat di depan mata juga di lengkapi dengan lensa untuk mempersisipkan jatuh bayangan harus berada di dalam kamera. Sistem Koneksi yang terintegrasi antara Raspberry Pi, kamera logitech c525, memory card, dan baterai berada di dalam case. Posisi LCD 4 inci diletakkan berapa di depan case untuk memudahkan pengontrolan sistem. Interkoneksi antar pin diagram dapat lebih jelas dilihat pada dan Gambar 6.

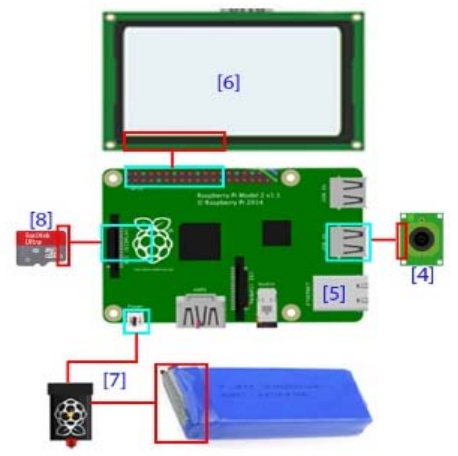

Gambar 6. Interkoneksi Pin Diagram

Berdasarkan gambar 5 dan 6 bagian-bagian komponen utama disusun Berikut yaitu:

1. Frame

2. Letak kamera

3. Posisi Liquid Crystal Display (LCD)

4. Kamera

5. Raspberry Pi 3 Model B+

6. Liquid Crystal Display (LCD)

7. Power Supply

8. Memory Card

\section{B. Perancangan Software}

Perancangan sistem dengan menggunakan image processing membutuhkan beberapa proses sehingga terbentuk suatu keputusan keluaran dari sistem deteksi ini dengan melakukan perancangan software. Pada sistem ini fungsi yang saling berhubungan dengan proses lain sehingga proses yang dihasilkan akan menjadi masukan dari proses berikutnya sampai menjadi keluaran akhir dari sistem berdasarkan hasil model yang telah dilatih tehadap sekumpulan data (dataset/database).

\section{Dataset}

Penggunaan dataset pada metode CNN yaitu berupa data citra iris mata. Dataset merupakan data yang akan digunakan sebagai acuan pada saat proses pengenalan gangguan ginjal pada saat pengujian dengan skema kerja dapat dilihat pada Gambar 7.

\section{Perancangan Arsitektur CNN}

Setelah dilakukan pembuatan data, langkah selanjutnya adalah melakukan perancangan arsitektur CNN. Umumnya dalam CNN memiliki dua tahapan, yaitu tahap feature learning dan classification. 


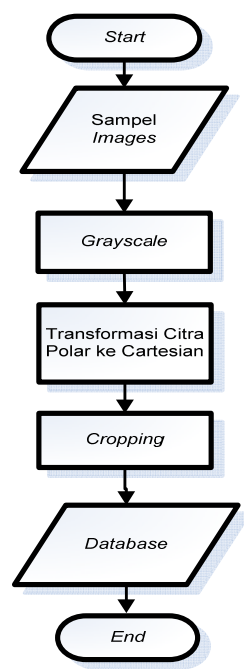

Gambar 7. Diagram alir Pembentukan Database Pelatihan

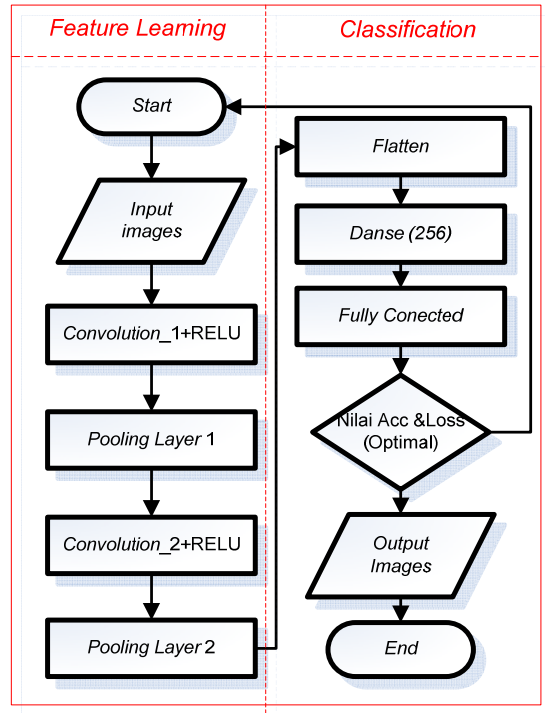

Gambar 8. Diagram alir CNN

Berdasakan gambar 8 masukan gambar pada model CNN menggunakan citra yang berukuran $64 \times 64 x 1$. Angka satu yang dimaksud adalah sebuah citra yang memiliki 1 channel masukan yaitu biner saja kemudian akan diproses terlebih dahulu melalui proses konvolusi dan proses pooling pada tahapan feature learning. Jumlah proses konvolusi pada rancangan ini memiliki dua lapisan konvolusi. Setiap konvolusi memiliki jumlah filter dan ukuran kernel yang berbeda. Kemudian dilakukan proses flatten atau proses mengubah feature map hasil pooling layer kedalam bentuk vektor. Proses ini biasa disebut

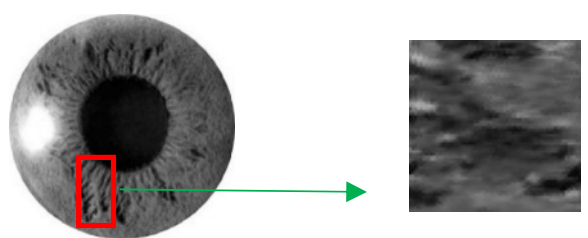

(a)

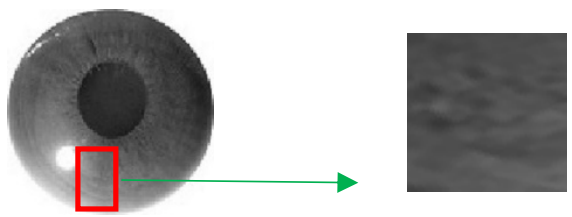

(b)

Gambar 9 Sampel (a) Gangguan Ginjal (b) Normal

dengan tahap fully connected layer. Kemudian dijelaskan terdapat dua tahap dalam arsitektur CNN, yaitu feature learning dan classification. Feature learning adalah teknik yang memungkinkan sebuah sistem berjalan secara otomatis untuk menentukan representasi dari sebuah image menjadi features yang berupa angka-angka yang merepresentasikan image tersebut. Tahap classification adalah sebuah tahap dimana hasil dari feature learning akan digunakan untuk proses klasifikasi berdasarkan subclass yang sudah ditentukan.

\section{Hasil dan Pembahasan}

\section{A. Hasil Pembentukan Dataset}

Pembentukan dataset merupakan proses utama dalam menentukan sampel iris mata untuk keperluan pelatihan. Sampel-sampel ini diambil dari pasien yang menderita gangguan ginjal dan normal juga dilengkapi sampel dari penelitian sebelumnya. Data sampel ini akan dijadikan data dataset yang terdiri dari dua kategori, yaitu gangguan ginjal dan normal yang dapat dilihat pada Gambar 15.

Pada gambar 9 dapat dilihat sampel iris mata kondisi gangguan ginjal atau normal dapat ditunjukkan pada bagian kotak merah. Sampel (a) merupakan sampel dengan gangguan ginjal yang memiliki kerusakan ditandai dengan lubang di dalam kotak merah. Sampel (b) merupakan sampel normal yang tidak terdapat kerusakan atau lubang di dalam kotak merah. Secara linier perbedaan dari dua sampel yang diambil terlihat dari tekstur kondisi iris mata yang berlubang dan tidak berlubang. 


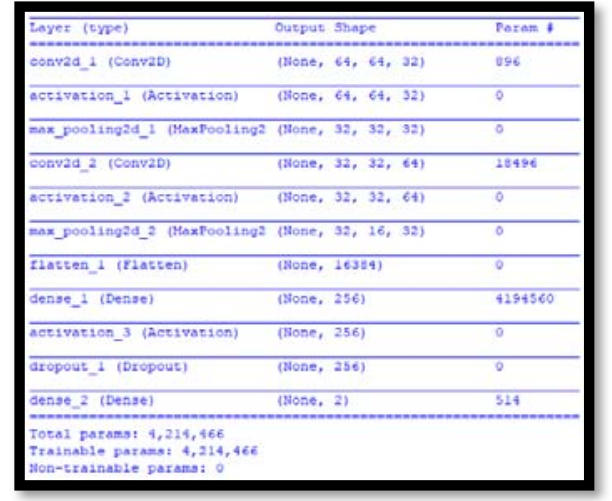

Gambar 10 Model Convolution Neural Network

Hasil pembentukan dataset terbagi menjadi dua kategori data yaitu train dan validation yang masingmasingnya terdapat dua kategori diagnosis yaitu gangguan ginjal dan normal. Terhadap 10 sampel train dan 2 sampel validation untuk masing-masing kategori diagnosis yang kemudian dilakukan penyebaran sampel yang terbagi menjadi empat tahap yaitu, proses penyebaran sampel terhadap intensitas cahaya, proses penyebaran sampel terhadap mirror, proses penyebaran sampel terhadap sudut kemiringan $-10^{0}$, proses penyebaran sampel terhadap sudut kemiringan $10^{\circ}$. Proses penyebaran sampel bertujuan meningkatkan efektifitas sehingga dataset yang terbentuk menjadi 200 sampel train dan 40 sampel validation untuk masing-masing kategori diagnosis.

\section{B. Arsitektur Jaringan}

Pada algoritma Convolutional Neural Network (CNN) pembentukan arsitektur jaringan dapat mempengaruhi sistem yang dibentuk serta mempengaruhi hasil dari akurasi model yang dirancang. Pelatihan jaringan menggunakan dua kategori diagnosis iris mata dengan ukuran $64 \times 64 \times 3$ yang bertujuan mengetahui pengaruh dan akurasi yang diperoleh. Arsitektur CNN yang terbentuk adalah 5 layer dan selanjutnya dilakukan proses klasifikasi. Proses klasifikasi ini menggunakan fungsi aktivasi softmax. Keluaran dari proses klarifikasi yaitu ada gangguan ginjal dan normal. Algoritma Convolutional Neural Network (CNN) pembentukan arsitektur jaringan dapat mempengaruhi hasil dari akurasi model. Arsitektur jaringan pada proses pelatihan didapatkan parameter yang terhitung. Sehingga dari proses training didapatkan model dari arsitektur yang terbentuk dapat dilihat pada Gambar 10.
Berdasarkan gambar 10 arsitektur model yang akan terbentuk dari hasil pelatihan dari 5 layer sehingga terbentuk parameter dari model yang dibuat sebanyak 4.214.466 parameter.

\section{Penentuan Parameter Arsitektur Jaringan Pelatihan CNN}

Penentuan model terbaik, harus dicari nilai terbaik parameter dalam model CNN. Parameter yang dimaksud adalah pengaruh jumlah epoch, pengaruh nilai learning rate, pengaruh ukuran kernel, pengaruh fungsi max pooling dan average pooling, pengaruh kombinasi data train dan data validation. Penentuan parameter model bertujuan mencari model terbaik dengan memperhatikan accuracy dan loss.

Dari hasil pengujian proses pelatihan model pada setiap perubahan nilai epoch menghasilkan validation accuracy mencapai $94 \%$. Namun, pada proses epoch sebanyak 3 dan 6 terjadi memiliki accuracy mencapai dibawah $75 \%$ dengan validation accuracy dibawah $75 \%$. Dapat dilihat pada kasus ini semakin tinggi nilai epoch yang digunakan maka semakin tinggi pula nilai accuracy yang dihasilkan. Tujuan melakukan pembatasan jumlah epoch yaitu untuk mengetahui pengaruh epoch dan sebaiknya harus mencari titik maksimal iterasi.

Pada pelatihan model setiap perubahan nilai learning rate menghasilkan akurasi tertinggi mencapai $86 \%$ dengan validation accuracy mencapai $92 \%$. Semakin kecil nilai learning rate maka akan meningkatkan akurasi. Namun, pada penelitian ini terjadi overfitting dalam proses pelatihan. Dapat dilihat pada loss dan validation loss, overfitting terjadi pada learning rate 0,01 . Hal tersebut mengakibatkan penurunan akurasi

Pada pelatihan model pada setiap perubahan ukuran kernel akurasi tertinggi mencapai 95\% dengan validation accuracy mencapai 95\%. Mencari kernel yang terbaik berdasarkan accuracy yang meningkat dan grafik yang memiliki peningkatan bertahap. Dapat dilihat pada validation accuracy dari pelatihan model untuk setiap perubahan ukuran kernel mepengaruhi nilai akurasi dan penambahan ukuran kernel yang semakin luas tidak selalu menghasilkan akurasi yang semakin baik.

Pada pelatihan model pada setiap perubahan kombinasi dataset akurasi tertinggi mencapai 85\% dengan validation accuracy mencapai 95\%. Pada 


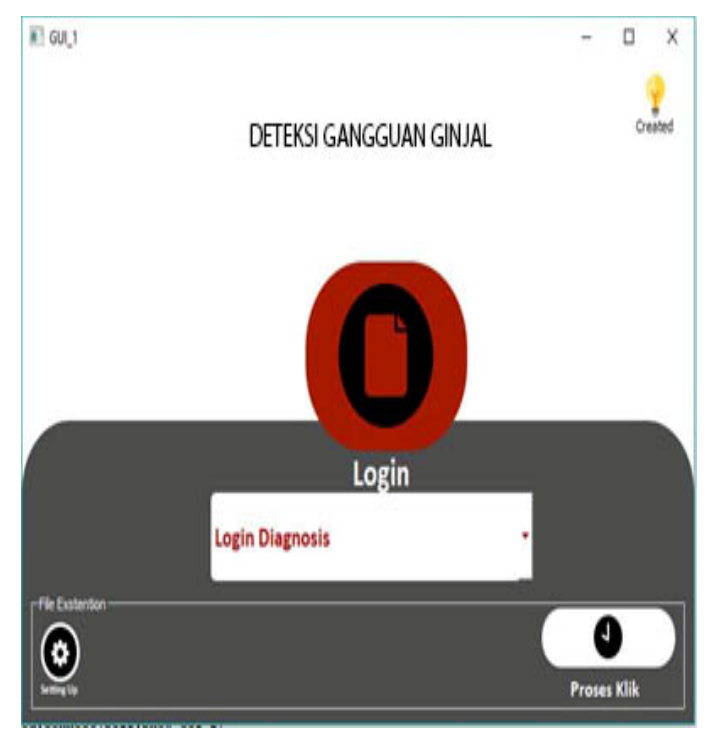

Gambar 11. GUI_1

penelitian ini terjadi penurunan validation accuracy ketika jumlah validation melebihi jumlah data train. Perubahan banyak data validation melebihi data train justru bukan semakin baik dalam menghasilkan accuracy dalam proses pelatihan tetapi malah menurunkan hasil akurasi.

Pada pelatihan model menggunakan max pooling dan average pooling yaitu dibawah 90\%. Menunjukkan accuracy validation dengan menggunakan max pooling lebih tinggi yaitu 90\% daripada menggunakan average pooling yaitu $85 \%$ pada permasalahan ini. Namun, tingkat akurasi dengan menggunakan metode max pooling ini tidak selalu menjadi yang terbaik, karena hal ini tergantung pada permasalahan yang dihadapi. Setiap perubahan pooling layer yang diberikan pada saat pelatihan data mempengaruhi waktu proses pelatihan.

\section{Proses Pengenalan}

Proses pengenalan merupakan proses uji sampel. Proses pengenalan terbagi menjadi tujuh pengujian diantaranya pengaruh terhadap nilai epoch, nilai learning rate, ukuran kernel, kombinasi data, pooling layer, perubahan sudut $10^{\circ}$, dan perubahan sudut $-10^{\circ}$. Gambar 11 merupakan tampilan dari GUI_1 yang terdiri dari combo box yang berfungsi sebagai jendal masukan untuk masuk ke GUI_2. Setelah memilih combo box "Login Diagnosis" selanjutnya menekan tombol "Proses klik" untuk memulai ke langkah selanjutnya dan akan muncul GUI_2 yang dapat dilihat Gambar 12.

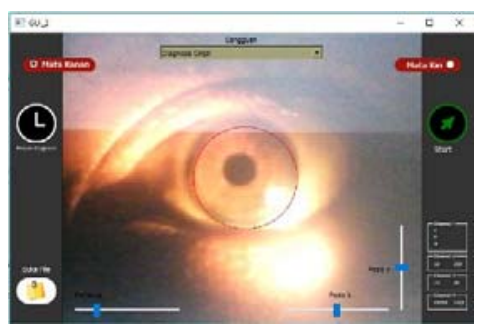

Gambar 12. GUI_2 Masukan

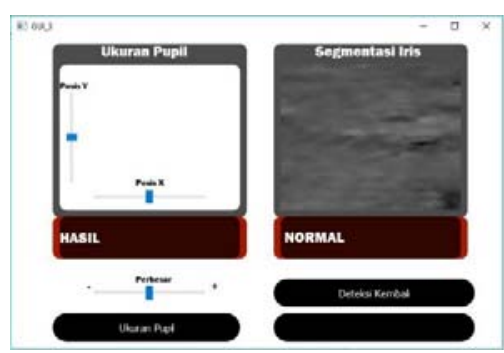

Gambar13. GUI_3 Proses Pengenalan Normal

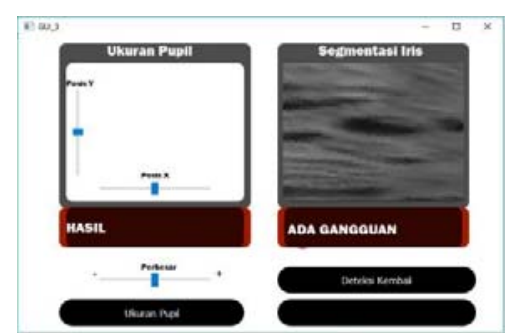

Gambar 14. GUI_3 Proses Pengenalan Ada Gangguan

Gambar 12 menunjukkan proses pengambilan gambar sedang berjalan. Pada bagian ini posisi lingkaran merah tepat berada di lingkaran mata dan untuk menyesuaikan posisi dan ukuran lingkaran merah bisa dilakukan penggeseran slider posisi $\mathrm{x}$ dan posisi y. Slider pembesar berfungsi untuk memperbesar diameter lingkaran merah untuk menyesuaikan ukuran lingkaran mata. Setelah menempatkan posisi lingkaran merah degan tepat selanjutnya untuk mendiagnosis gangguan ginjal dapat menekan tombol "Proses Diagnosis" menuju ke proses selanjutnya dapat dilihat pada gambar 13 .

Pada gambar 13 dapat dilihat hasil dari proses pengenalan gangguan ginjal dengan prediksi normal dan terlihat pada segmentasi iris tidak terbentuk iris mata yang berlubang dan sesuai dengan prediksi yang ditampilkan yaitu "Normal". 


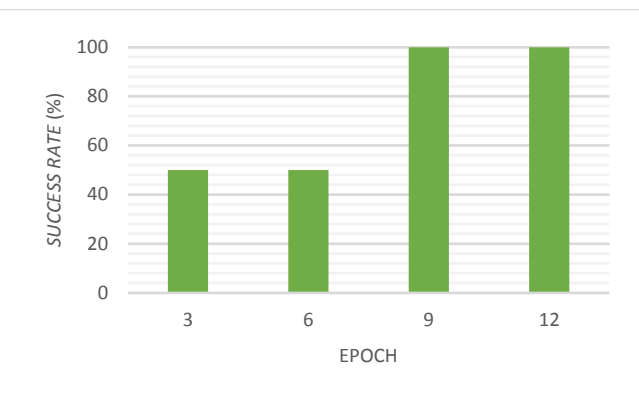

Gambar 15. Grafik Perbandingan Success Rate Terhadap Perubahan Epoch

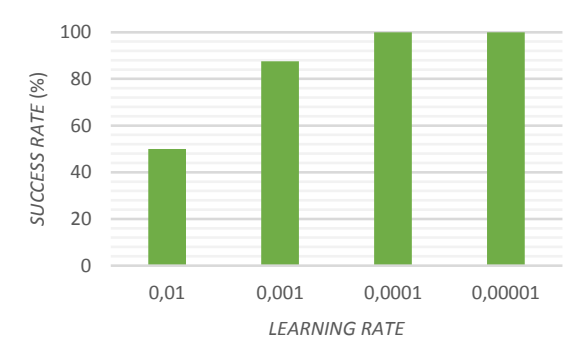

Gambar 16. Grafik Perbandingan Success Rate Terhadap Perubahan Nilai Learning Rate

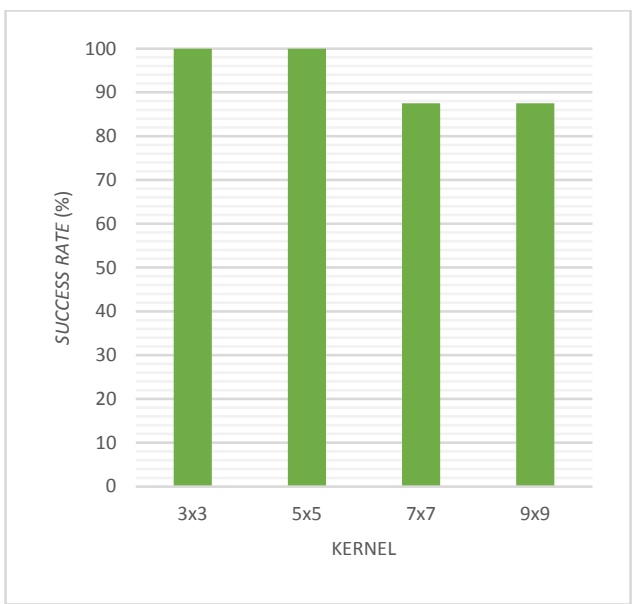

Gambar 17. Grafik Perbandingan Success Rate Terhadap Perubahan Ukuran Kernel

Pada gambar 14 dapat dilihat hasil proses pengamatan gangguan ginjal degan prediksi "Ada Gangguan" dan terlihat pada segmentasi iris terlihat iris mata yang terlihat dan berlubang. Iris mata yang terbentuk akan menjadi acuan terhadap penentuan selanjutnya.

Proses utama mendiagnosis gangguan kesehatan selanjutnya diuji terhadap pengaruh masing-masing parameter yang diukur untuk mengetahui akurasi yang dihasilkan.

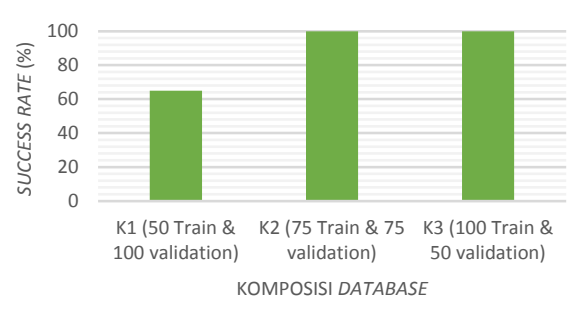

Gambar 18. Grafik Perbandingan Success Rate Terhadap Perubahan komposisi database

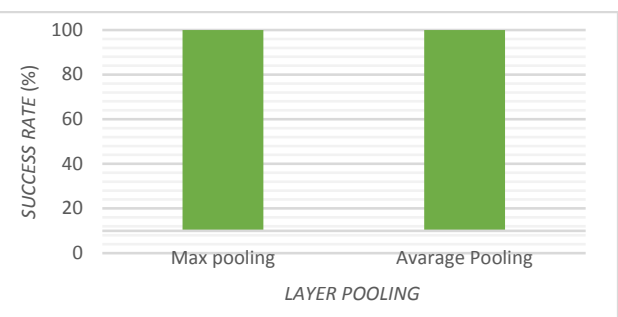

Gambar 19. Grafik Perbandingan Success Rate Terhadap Perubahan Pooling Layer

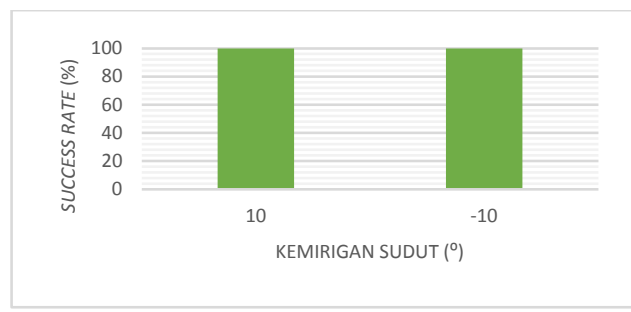

Gambar 20. Grafik Perbandingan Success Rate Terhadap Perubahan Sudut

Berdasarkan gambar 15 terlihat bahwa hasil uji iris mata untuk gangguan ginjal terhadap grafik perbandingan success rate terhadap perubahan epoch. Success rate tertinggi yaitu $100 \%$ pada model 9 epoch dan 12 epoch. Salah satu kekurangan CNN pada pengujian ini adalah tidak adanya memori penyimpanan sementara sehingga tidak ada acuan dalam mengambil nilai tertinggi pada saat pemodelan sehingga mengurangi tingkat success rate. Pembatasan penggunaan epoch juga mempengaruhi sistem dalam mempelajari pola sehingga jaringan belum sampai ke model yang tepat untuk memprediksi diagnosis iris mata. Pada pengujian di atas bisa digunakan sebagai program acuan penentuan diagnosis iris mata. Berdasarkan data uji success rate yang didapatkan sesuai dengan data akurasi hasil pelatihan yang dilakukan.

Berdasarkan gambar 16 terlihat bahwa hasil uji iris mata untuk gangguan ginjal terhadap grafik 
perbandingan success rate terhadap perubahan nilai learning rate. Success rate tertinggi yaitu $100 \%$ pada saat nilai learning rate yaitu 0,0001 dan 0,00001 . Success rate terendah yaitu $50 \%$ pada saat nilai learning rate yaitu 0,01 . Pemilihan filter secara acak dalam pelatihan mempengaruhi model yang dipelajari sehingga terjadinya overfitting pada dataset dan jaringan tidak dapat mengambil sinyal yang mewakili ciri dari gambar iris mata. Penggunaan nilai learning rate yang terlalu besar atau terlalu kecil tidak selalu menghasilkan nilai success rate yang selalu baik. Pada pengujian di atas bisa digunakan sebagai program acuan penentuan diagnosis iris mata. Berdasarkan data uji success rate yang didapatkan sesuai dengan data akurasi hasil pelatihan yang dilakukan.

Berdasarkan gambar 17 terlihat bahwa hasil uji iris mata untuk gangguan ginjal terhadap grafik perbandingan success rate terhadap perubahan ukuran kernel Success rate tertinggi yaitu $100 \%$ pada saat ukuran kernel $3 \times 3$ dan $5 \times 5$. Success rate terendah yaitu $87,5 \%$ pada saat ukuran kernel $7 \times 7$ dan 9x9. Ukuran kernel sangat mempengaruhi jumlah matriks keluaran setelah melewati layer konvolusi. Semakin besar ukuran kernel semakin banyak komputasi yang dilakukan sehingga dapat sistem perlu mempelajari parameter lebih banyak. Penggunaan ukuran kernel yang semakin luas tidak menghasilkan nilai success rate yang baik dan menggunakan waktu yang semakin lama. Pada pengujian di atas bisa digunakan sebagai program acuan penentuan diagnosis iris mata. Berdasarkan data uji success rate yang didapatkan sesuai dengan data akurasi hasil pelatihan.

Berdasarkan gambar 18 terlihat bahwa hasil uji iris mata untuk gangguan ginjal terhadap grafik perbandingan success rate terhadap perubahan komposisi database. Success rate tertinggi yaitu 100\% pada saat K2 dan K3. Success rate terendah yaitu $62,5 \%$ pada saat K1. Turunnya performa success rate diakibatkan karena pengurangan jumlah data train sedangkan data validation ditingkatkan. Kecilnya data validation juga tidak selalu baik tetapi komputasi akan semakin cepat ini dikarenakan sedikitnya pola iris mata yang dikenali dan pada dasarnya minimal penggunaan banyak data validation yaitu $30 \%$ dari data train. Pada pengujian di atas bisa digunakan sebagai program acuan penentuan diagnosis iris mata. Berdasarkan data uji success rate yang didapatkan sesuai dengan data akurasi hasil pelatihan.
Berdasarkan gambar 19 terlihat bahwa hasil uji iris mata untuk gangguan ginjal terhadap grafik perbandingan success rate terhadap perubahan layer pooling. Success rate yaitu $100 \%$ pada saat max pooling. Success rate terendah yaitu $87,5 \%$ pada saat average pooling. Turunnya performa Success rate diakibatkan karena pada prosesnya mengkalkulasikan nilai rata-rata sehingga dapat mempengaruhi gambar disebelahnya akibatnya banyak sifat gambar grayscale yang mewakili ciri tidak terbaca secara sempurna dan samar-samar. Berdasarkan data uji success rate yang didapatkan sesuai dengan data akurasi hasil pelatihan yang dilakukan.

Berdasarkan gambar 20 terlihat pada sudut kemiringan $10^{\circ}$ success rate yang dihasilkan yaitu $100 \%$ dan pada sudut kemiringan $-10^{\circ}$ success rate yang dihasilkan yaitu $100 \%$. Dapat disimpulkan dari penelitian yang dilakukan hasil uji yang didapatkan sesuai berdasarkan nilai accuracy pada saat proses pelatihan. Jika menginginkan hasil yang baik tentunya nilai accuracy pada saat proses pelatihan harus diperhatikan dan ditingkatkan. Beberapa faktor yang mempengaruhi nilai accuracy diantaranya dari segi teknis dimulai dari pengguaan kamera yang digunakan yang memiliki kualitas standard. Selain itu, faktor lainnya yaitu lensa yang berdebu sehingga dapat mengubah titik fokus dan kondisi cahaya yang kurang dapat membuat gambar menjadi buram. Kemudian faktor pendukung rendahnya accuracy yang dihasilkan yaitu penggunaan database yang sedikit karena untuk memahami sebuah gambar baru memerlukan data yang sangat banyak sebagai data acuan. Nilai rata-rata accuracy yang didapatkan hasil uji dalam penelitian ini mencapai $100 \%$.

\section{Kesimpulan}

\section{PENUTUP}

Akurasi terbaik yang diperoleh dengan memvariasikan banyak epoch, nilai learning rate, ukuran kernel, komposisi database, dan fungsi pooling layer adalah $94 \%$ pada saat epoch $12,92 \%$ pada nilai 0,0001, 95\% pada ukuran $3 \times 3,95 \%$ pada komposisi 100 train dan 50 validation, $90 \%$ menggunakan fungsi max pooling.

Akurasi pengenalan ganguan ginjal dengan menggunakan metode convolutional neural network citra iris mata pada Raspberry Pi Model 3 B+ adalah $100 \%$. 


\section{DAFTAR PUSTAKA}

[1] Aisara, Sitifa, dkk. 2018. Gambaran Klinis Penderita Penyakit Ginjal Kronik yang Menjalani Hemodialisis di RSUP Dr. M. Djamil Padang. Padang: Universitas Andalas.

[2] Fresenius Medical Care. 2012. ESRD Patients in 2012: A Global Perspective.

[3] Lathifah, Annis Umi. 2016. Faktor Risiko Kejadian Gagal Ginjal Kronik Pada Usia Dewasa Muda di RSUD dr. Moewardi. Skripsi. Surakarta: Universitas Muhammadiyah Surakarta.

[4] Trihono. 2013. Riset Kesehatan Dasar. Jakarta: Badan Penelitian dan Pengembangan Kesehatan Kementrian Kesehatan RI.

[5] Jensen, B. 1982. What is Iridology. Ben Jensen Enterprise Publishers. California.
[6] Setiawan, Bambang. 2009. Identifikasi Iris Mata Menggunakan Metode Hidden Markov Model. Tesis. Depok: Universitas Indonesia.

[7] Nurhikmat, Triano. 2018. Implementasi Deep Learning Untuk Image Classification Menggunakan Algoritma Convolutonal Neural Network (CNN) Pada Citra Wayang Golek. Skripsi. Yogyakarta: Universitas Islam Indonesia.

[11] Danukusumo, Kevin Pudi. 2017. Implementasi Deep Learning Menggunakan Convolutional Neural Network untuk Klasifikasi Citra Candi Berbasis GPU. Skripsi. Yogyakarta: Universitas Atma Jaya Yogyakarta.

[12] Srivastava, N., Hinton, G, and Kriszhevsky, A. (2014). Dropout: A Simple Way to Prevent Neural Network. Journal Conference Learning Research, 19291958. 